fairly comparable to that of a machine with a hidden defect. So long as the injured employee has not departed from his duties, it would seem that he should be granted compensation under the acts. ${ }^{21}$

The principal case is an illustration of the application of the subjective test of knowledge in order to reach a correct result, but without a clear analysis of the implications involved in the doctrine. Here the employer was fairly chargeable with knowledge of the youth of the coëmployee and perhaps also of the presence of the pistol since that was known to a "number of employees." But there were no evidential facts to show knowledge of the "character or habits" of the employee. ${ }^{22}$ Hence knowledge of such facts is either imputed or unnecessary, i. e., it is not one of the operative facts creating the employer's duty to pay compensation. This means, in either event, that among the operative facts are the boy's age, disposition, etc., and the employer's knowledge of the same is not included. This being so, the requirement of knowledge is misleading and to give full effect in the future to the desirable result reached in the case under discussion, it will be necessary to discard entirely the pseudo-limitation attempted to be attached to the principles involved.

FAILURE TO TRANSMIT AN OFFER AS A TORT

It has been held the offeree's silence may be the equivalent of an affirmative act of acceptance of an offer so as to make a binding contract. ${ }^{1}$ Obviously such cases will be comparatively rare since the offeror cannot be permitted to compel the offeree to take action to avoid being bound by a contract unless the offeree's previous actions or the circumstances of the parties justify. But may there not be a breach

${ }^{21}$ Szift v. Industrial Commission (I919) 287 Ill. 564, I22 N. E. 796. This position is strengthened by the fact that the same courts do allow recovery where the injury is the indirect result of a practical joke. "How can his rights be affected by the fact that the man who placed the can on the die says he did so 'just to have some fun.'" Knopp v. American Car Co. (1914) I86 Ill. App. 605.

22 "There can be no serious contention that the injury did not arise out of his employment. Garls was required to present the slip given him at the window of the office of plaintiff-in-error to receive his pay. Complying with this regulation and standing in line waiting his turn he was jostled and thrown down and injured through no fault of his own. It does not appear that he was engaged in any jostling or "horseplay" or that he in any way was responsible for the injury he sustained." Pekin Cooperage Co. v. Industrial Board (IgI7) 277 Ill. 53,115 N. E. 128.

${ }^{1}$ See Comment (I920) 29 Yale Law Journat, 44I, criticising Cole-McIutyreNorfleet Co. v. Holloway (rgrg, Tenn.) 2I4 S. W. 817. See also (rg20) 33 HARv. L. Rev. 595; Corbin, Offer and Acceptance and Some of the Resulting Legal Relations (I9I7) 26 YAlE LAW JourNAL, 20a; Ostman v. Lee (I9I7) gr Conn. 731, IaI Atl. 23, (1918) 27 YALE LAW Journal, 272; I Williston, Contracts (1920) sec. 9I; I Page, Contracts (2d ed. Ig20) sec. I60. 
of duty for which the offeror may recover damages. where silence results from the failure of the offeree's agent to report to his principal the offer he has solicited ?

Now the question as to the existence of a duty to answer an offer promptly may arise when either the offer is made directly to the offeree or when it is made to the offeree's agent. In the former case the situation seems clearly one where each party knows that the offeree's volition is alone involved and hence mere delay in acting cannot be considered a negligent breach of duty. It may show an acceptance of the contract, ${ }^{3}$ it may be a breach of a collateral contract either to accept or reject under certain conditions, ${ }^{4}$ or it may, where the offer has expired by lapse of time, demonstrate that the offer was not to be accepted..$^{5}$ Other than this apparently it can have no operative effect.

Where the offer is made to the offeree's agent, however, there would seem to be occasions where the agent's negligence is a breach of duty which renders the principal liable in damages. The essential fact in the creation of such a duty is not mere delay in acceptance, but is the agent's failure to present the offer to his principal for acceptance within a time considered proper under the facts of a particular case. Thus in a well considered insurance case, application was made for life insurance, the agent neglected to forward the application, and the applicant died before action was taken upon the application although according to the company's usual course of business action should have been taken before the death occurred. Recovery was had against the company on the theory that the agent was negligent. ${ }^{8}$ The question arose in the recent case of Four States Grocer Co. v. Wickendon (I9I9, Tex.)

2 The negative answer seems to be suggested in (I920) 33 HARv. L. REv. 595, note 6.

${ }^{3}$ See note $\mathrm{I}$, supra.

- Note (Ig18) 27 Yale Law Journal, 56r, criticising Evans Piano Co. v. Tully (IgI7) II6 Miss. 267,76 So. 833.

I Williston, op. cit., sec. 53.

'Duffie v. Bankers' Life Ass'n (1913) I60 Iowa I9, 139 N. W. 1087, approved in (I913) 27 Harv. L. REv. 92. See also (I913) I3 CoL. L. Rev. 647; (I913) II Mich. L. Rev. 606. In accord see Boyer v. State Farmers' Mutual Hail Irs. Ass'n (I9I2) 86 Kan. 442, I2I Pac. 329, 40 L. R. A. (N. S.) I64, note: Wilken v. Capitol Fire Ins. Co. (1916) 99 Neb. 828, I57 N. W. IO2I ; contra, Nat'l Fire Ins. Co. v. School District (1916) 122 Ark. I79, I82 S. W. 547; Dorman v. Conn. Fire Ins. Co. (1914) 4I Okla. 549, I39 Pa. 262. Compare Meyer v. Central States Fire Ins. Co. (1919, Neb.) 173 N. W. 578; Trask v. German Ins. Co. (1893) 53 Mo. App. 625; (1894) 58 Mo. App. 431. Some cases hold that failure to communicate rejection of an application for insurance within a reasonable time constitutes an acceptance, but the general rule is contrary. See cases collected (1919) 33 HARv. L. REv. 206, notes 40 and 41 ; 40 L. R. A. (N. S.) I64; 36 L. R. A. (N. S.) I2Ir. The Duffie case relies partly on the contention that insurance is a public calling. Notwithstanding the ingenious argument by Patterson, The Delivery of a Life Insurance Policy (Igrg) 33 HARv. L. REv. 216- 
2I7 S. W. IIO3, where one Joplin, agent for the grocer company, took an order from Wickendon in October, 19I6, for 3 bales of duck to be shipped August I, I9I7, "order taken subject to acceptance" of the company. Joplin did not send the order to the company which first heard of it when Wickendon wrote on July 5, 'I9I7, asking that shipment be made during the following month. Upon the company's refusal to ship the goods at the price stated in the order Wickendon sued for damages and recovered a verdict and judgment. The court now reverses this judgment and orders judgment entered for the company.

Wickendon had brought his action in two counts, one in ordinary form for breach of contract, while in the other he stated the facts in detail and alleged that he believed his order had been accepted as he had no notice to the contrary until.July, I9I7, that he failed to purchase duck as he otherwise would and has now been forced to purchase in the open market at a much higher price and that the defendant is now estopped from denying the making of a contract, because of the negligence of its salesman and the plaintiff's belief that his order had been received. The court in its opinion seems to concede the vital element of the plaintiff's case, as it says that "Joplin personally owed both his employer and his customer the duty to promptly transmit orders taken in the course of his business." It then curiously bases its decision for the company on the ground that Joplin's breach of duty was not that of his employer. This holding must surely be erroneous, for Joplin was certainly acting within the scope of his authority in transmitting orders to the company: that was very nearly the only thing he was to do under his contract of employment. Hence if the duty exists upon Joplin's part-and there is more question about this than the court indicates-it must also exist upon his employer's part. The court was doubtless misled by the fact that the plaintiff attempted to work out a contract by estoppel instead of stating directly a cause of action based upon the agent's negligent failure to transmit the offer.'

Should such a duty of promptly transmitting the offer be held to

218 , that in view of the nature of the business, insurance should be effective upon presentation of a proper application without reference to acceptance, it seems clear that the company should be privileged to reject risks without regard to its reasons, i. e., to choose those with whom it wishes to deal. Richards, Insurance (3d ed. 1910) secs. 60, 94. Hence the criticism of the Duffie case on this point in (rgi3) 27 HARv. L. REv. 92, seems correct. If, however, the company may be held for its agent's failure to transmit an application promptly, the applicant is reasonably well protected against the company's delay.

'The court says: "To' hold that the appellant owed the duty of transmitting to itself for confirmation orders taken in that manner would be absurd. The very fact that the order must be accepted before the contract is made shows that the appellant was in no sense a party to the transaction of taking the order. Joplin had no authority to bind it in any manner." The cases cited in note 6 , supra, as being contra to the Duffie case seem to question the agent's authority. 
exist $^{8}$ There are these arguments to the contrary: (I) the lack of judicial precedents may indicate that such a duty is not contemplated or relied upon in ordinary business practice; (2) since a similar duty seems not to exist when the offer is made directly to the offeree it may be unreasonable for the offeror to rely on the existence of a duty in this case; and (3) the offeror may protect himself with comparative ease either by limiting the duration of the offer or by entering into a collateral contract with the agent for an early reply, (such contract apparently being within the scope of the agent's authority) or by making prompt inquiries. Nevertheless it is submitted that such a duty should be held to exist and that it is more in accord with business practice so to hold. The agent's main business is to transmit the offer and surely the offeror may expect that the agent will do what he is apparently hired to do. It is not to be expected that the offeror will wish to limit his offer, all the more if, as would seem from his making it, it is advantageous. Nor should he be required to protect himself in a way which would thus limit the possibility of making a contract and hence be disadvantageous to both parties. Then if it is his place to make inquiries, when must he start to inquire, that is, when is he to expect that his offer has gone astray? Is it not unfair to make him responsible for a failure to guess correctly? Moreover it is well known that the provision requiring acceptance is only a matter of protection to the seller, and non-acceptance will be the unusual course. ${ }^{8}$ Else why is the agent soliciting orders? In common judgment one buys from the agent. If the seller has made it an offer instead of a sale it but accords with business practice to put the affirmative duties connected with acceptance upon the seller. Therefore rather than force the buyer to make inquiries, it is fairer to hold that the duty of transmission rests upon the agent. It might be feasible to consider that under the circumstances there was an implied contract to reply promptly to the offer, but as there seems to be a negligent breach of duty it is unnecessary to resort to presumptions as to the intentions of the parties. ${ }^{10}$

If such duty exists, it would seem breached whether the offer would have been accepted or not. ${ }^{11}$ The acceptability of the offer-a ques-

\footnotetext{
${ }^{8}$ Since a suit for the agent's negligence will lie against either the agent or the principal, where the agent is acting within the scope of his authority, the question here of duty owed by the principal to the offeror is identical with that of duty owed by the agent to the offeror and vice versa.

- Star Clothing Mfg. Co. v. Jones (1920, Ark.) 218 S. W. 175, a suit by an agent to collect from his employer commissions on sales. It was held that the employer had as to the agent a duty to accept all orders from bona fide purchasers made in accordance with the provisions previously specified and could not refuse to accept because of an advance in market price beyond that at which the agent was authorized to sell.

${ }^{10}$ Duffie v. Bankers' Life Ass'n., supra, p. 24 of 160 Iowa.

${ }^{11}$ In Duffie $v$. Bankers' Life Ass'n., supra, it is expressly stated by the court that the jury might have found that in all reasonable probability the application would have been accepted. But note Dorman v. Comm. Fire Ins. Co., supra.
} 
tion of fact for the jury-would affect simply the question of damages. If the offer was unacceptable, the damages would be only nominal. Here, too, an unreasonable delay upon the part of the offeror in making inquiries may be important as showing that he could not reasonably have relied so long on the expected acceptance of the contract and should have taken steps to mitigate the damages. Such questions would then all be matters of fact for the jury's decision in determining the amount of recovery.

Another question occurs where the offer is that of a proposed contract for the benefit of a third person. To whom is then the duty here in question owed? In the insurance case ${ }^{12}$ it was held that it was owed to the estate of the decedent and not to the proposed beneficiary. This seems unjust, for the substantial loss falls upon the beneficiary and not upon the creditors or heirs of the applicant. The loss is that of an expectancy and while the courts have been slow to believe that interference with an expectancy is a breach of a duty, yet the trend of decisions seems that way. ${ }^{13}$ Where the offeror goes so far as to make an offer of a contract for the benefit of a third party, the requirement of "immediacy" of the expectancy would seem to be satisfied. ${ }^{14}$ Hence there would be a breach of duty to the offeror, whose damages are nominal and a breach of duty to the beneficiary, whose damages are substantial. But in jurisdictions where such beneficiary is held not to have a right against the promisor of a contract, this rule of law would prevent the legal recognition of the expectancy in this class of cases. ${ }^{15}$

C. E. C.

\section{CONSTITUTIONAL UNLIMITATIONS}

Again the question of free speech has come before the Supreme Court, this time in Schaefer v. United States (March I, I920) Oct. Term, IgIg, Nos. 270-274. The opinions add little to the Abrams case. ${ }^{1}$ The majority (Justice McKenna) states the contention of the defendants indicted under the Espionage Law as that "the morale of the armies when formed could be weakened or debased by question

${ }^{12}$ Duffie v. Bankers' Life Ass'n., supra.

${ }^{12}$ See cases collected in (I9I8) 28 Yale Law Journal, 507. The cases of injunctions against labor unions are perhaps the commonest. In Hall $v$. Hall (IgI7) 9I Conn. 5I4, (IgI7) $27^{\circ}$ Yale LAw Journal, 263, such an action in connection with an expectancy as heir was denied. But see strong dicta in Lewis v. Corbin (I907) 195 Mass. 520. An early case is Tarleton v. McGarvley (i793) Peake, 205.

14 (19I8) 28 Yale Laiw Journal, 507.

${ }^{13}$ But the rule urged in the text should nevertheless exist even in such jurisdictions in the case of life insurance policies, since the beneficiaries are generally permitted to sue upon the policies. I Williston, op. cit., sec. 369 .

${ }^{2}$ (rgrg) 40 Sup. Ct. 17. See, for discussion of that case and of the principles involved, Com Ment (I920) 29 Y YLE Law Journad, 337. 